\title{
Tarımsal ilaçlamada kullanılan bazı memelerin farklı püskürtme yüksekliği ve basınç düzeylerinde oluşturduğu püskürtme dağılımının belirlenmesi
}

\author{
Determination of spray distribution of some nozzles used in agricultural at different \\ spray height and pressure levels
}

\author{
Ali BOLAT ${ }^{1}$, Ali BAYAT ${ }^{2}$ \\ ${ }^{1}$ Doğu Akdeniz Tarımsal Araştırma Enstitüsü Müdürlüğü, Adana, Türkiye \\ ${ }^{2}$ Çukurova Üniversitesi, Ziraat Fakültesi, Tarım Makinaları ve Teknolojileri Bölümü, Adana, Türkiye \\ Sorumlu yazar (Corresponding author): A. Bolat, e-posta (e-mail): bolat.ali@tarimorman.gov.tr \\ Yazar(lar) e-posta (Authore-mail): alibayat@cu.edu.tr
}

\section{MAKALE BILLGISİ}

Alınış tarihi 18 Nisan 2019

Düzeltilme tarihi 14 Ekim 2019

Kabul tarihi 18 Ekim 2019

\section{Anahtar Kelimeler:}

Püskürtme memesi

Püskürtme dağılımı

Püskürtme paternatörü

Varyasyon katsayısı
ÖZ

$\mathrm{Bu}$ araştırmada, tarımsal ilaçlamalarda kullanılan standart yelpaze hüzmeli (XRN 11003), hava emişli yelpaze hüzmeli (AIXR 11003) ve hava emişli ikiz hüzmeli (AITTJ60 11003) memelerin iki farklı püskürtme yüksekliğinde $(40$ ve $50 \mathrm{~cm}$ ) ve üc farklı püskürtme basıncında (3,4 ve 5 bar) işletilmesi ile oluşan püskürtme dağlımları belirlenmiştir. Denemelerde laboratuvar koşullarında standart bir oluklu tek memeli bir paternatör ile her bir memenin sağladığı püskürtme dağılımları ölçülmüștür. Her bir meme için oluşan varyasyon katsayıları paternatör üzerinde oluşan püskürtme dağılımlarına göre hesaplanmış̦ır. Araştırma sonuçlarına göre, en düsük varyasyon katsayıları $40 \mathrm{~cm}$ püskürtme yüksekliğinde ve 5 bar basınçta XRN meme tipinde $\% 40.7$ ile, AIXR meme tipinde $\% 47.6$ ve AITTJ60 meme tipinde $\% 52.6$ bulunmuştur.

\section{ARTICLE INFO}

Received 18 April 2019

Received in revised form 14 October 2019

Accepted 18 October 2019

\section{Keywords:}

Spraying nozzle

Spray distribution

Spray patternator

Coefficients of variation

\begin{abstract}
In this study, were analyzed the influence of three different spray nozzles, which are standard flat fan nozzle (XRN-11003), air induction flat fan nozzle (AIXR-11003) and air induction turbo twin-jet nozzle (AITTJ60-11003) have been determined in two different spraying heights $(40-50 \mathrm{~cm})$ with three different operating pressure (3-4 and 5 bar) according to volumetric liquid distributions. The experiments were analyzed in laboratory conditions to determine the spray patterns of the nozzles connected to a normal corrugated patternator under different operating conditions. The coefficients of variation for each nozzle were calculated based on the measured fluid amount on the patternator. According to the results of the study, the lowest coefficients of variation were delivered at $40 \mathrm{~cm}$ spray height and 5 bar pressure, $40.7 \%$ for XRN nozzle type, $47.6 \%$ for AIXR nozzle type and $52.6 \%$ for AITTJ60 nozzle type.
\end{abstract}

\section{Giriș}

Tarımsal üretimde hastalık, zararlı ve yabancı otlar ile mücadelede pestisitler yaygın olarak kullanılmaktadır. Pestisitlerin uygulanmasında kullanılan pülverizatörler ve memenin özelliklerinin iyi bilinmesi ilaçlamanın başarısı bakımından kritik öneme sahiptir. İlaçlama memesi, pülverizatör deposundaki sıvının hedef alana doğru parçalanarak iletilmesini ve daima sabit debi ile püskürtülmesini sağlayan en önemli bir pülverizatör organıdır. Bu nedenle ilaçlama memesinin ve memeye ait işletme koşullarının (püskürtme yüksekliği, işletme basıncı vb.) iyi bilinmesi, sıvının homojen olarak hedef alana iletilmesi ve sürüklenmenin azaltılması bakımından oldukça önemlidir. Özellikle sürüklenmenin azaltılmasına yönelik olarak en çok başvurulan yöntemler; püskürtme basıncının ve uygulama yüksekliğinin yönetilmesidir. Bilindiği üzere püskürtme basıncının düşürülmesi ve püskürtme yüksekliğinin azaltılması ilaç sürüklenmesinin azaltılması sağlanabilir. Pülverizatörlerde yaygın olarak kullanılan meme tipleri arasında yelpaze hüzmeli ve konik hüzmeli memeler yer almaktadır. Ancak imalatçılar pestisit uygulama teknolojilerinin iyileştirilmesine yönelik olarak ilaç kayıplarını azaltan, damlaların hedefte toplanma etkinliğini artıran ve sürüklenmeyi azaltabilen hava emişli 
memeleri üretmişlerdir. $\mathrm{Bu}$ memeler, standart tip yelpaze hüzmeli memelere göre aynı verdi ve çalışma basıncında daha büyük çaplı damlalar üretmektedirler. Yeni nesil olarak adlandırılan bu memelerde, gövde içerisinde ön orifis odasıyla birlikte bir venturi bulunmakta ve siviyla birlikte gövdeye hava girişi sağlanmaktadır. Sıvının giriş basıncı ön orifis odasında azaltılırken, memelerden çıkan damlalar içerisinde daha küçük damlacıkları taşıyan iri damlaları oluşmaktadır (Caner ve ark. 2015). Böylece, standart yelpaze hüzmeli memelere göre, sürüklenme eğilimi daha az olan damlalar ile hedef alan üzerinde daha homojen bir dağılım sağlanmaktadır (Sayıncı ve Bastaban 2009). Diğer taraftan hedef yüzey alanda uygulanan kimyasal ilacın kaplama oranını ve penetrasyon etkinliğini arttırmak amacıyla çift yarıklı (ikiz hüzmeli) meme tipleri kullanılmaya başlanmıştır. Yapılan çalışmalarda hava emişli memeler ile aynı işletme koşullarında ilaç dağılımının standart memelere göre $\% 50$ oranında iyileştiği belirtilmiştir (Vincelli ve Dixon 2007). Ancak özellikle yeni geliştirilen hava emişli ve ikiz hüzmeli memelerde püskürtme yüksekliği ve basıncın değiştirilmesine bağlı olarak, meme püskürtme desenindeki değişim düzeyleri bilinmemektedir.

Püskürtme yüksekliği, ilaçlama başarısını etkileyen önemli parametrelerden bir tanesidir. Memeden parçalanarak hedefe yönlendirilen sıvının homojen olarak iletilebilmesi ve belirli yükseklikte üst üste bindirilerek yeterli kaplama sağlaması gerekmektedir. Forney ve ark. (2017), ilaçlamada püskürtülen sıvının memeden çıkış yüksekliğinin, hedef alanlardaki püskürtme başarısına ve damla dağılımına etkili olduğunu belirtmişlerdir. İlaç dağılım düzgünlüğüne ve damla oluşuma etkili en önemli püskürtme parametrelerinden bir tanesi de meme püskürtme basıncıdır. Pestisit uygulamalarında basınç değeri de önemli parametrelerden bir tanesidir. Faqiri ve Krishnan (2005) püskürtme basıncının damla dağılımına doğrudan etkili olduğunu belirtmişlerdir. Carroll (2017), püskürtme basıncinın artması ile orifisi terk eden hacimsel damla çapının azaldığı ve daha homojen bir dağılım deseni oluşabildiğini belirtmiştir. Womac ve ark. (2001), venturi tip hava emişli memelerde püskürtme dağılımının basınç artışıyla birlikte iyileştiğini belirlemiştir. Benzer şekilde Sehsah ve Kleisinger (2009) damla dağılım üniformitesinde meme tipi ve püskürtme basıncının etkili olduğunu vurgulamışlardır.

İlaçlama memesi performansının en önemli göstergesi püskürtme dağılım düzgünlüğü olup, hacimsel sıv1 dağglımındaki tekdüzeliği ifade etmektedir. Püskürtme desenindeki hacimsel dağılım düzgünlüğü varyasyon katsayısı ile hesaplanmaktadır. Višackilve ark. (2017), ilaçlama memelerinde püskürtme dağılım düzgünlügünün paternatörde kontrol edilebildiğini ve homojen bir dağılım için varyasyon katsayısı küçük olması gerektiğini belirtmişlerdir. İlaçlama memelerinin başarısını test eden birçok çalışmada sıvının bir paternatör üzerinde çalıştırılması sırasında oluşan dağılım

düzgünlüğüne ait varyasyon katsayısı incelenmiştir. Subr ve ark. (2017), püskürtme varyasyon katsayı değerlerini belirleyerek yeni ve kullanılmış aynı tip memelerde sıvı dağılımının etkilerini araştırmışlardır. Sayıncı ve ark. (2017), konik hüzmeli meme plakalarında farklı girdap plaketi ve püskürtme basıncı kombinasyonlarının püskürtme dağılımı ve hüzme açısına olan etkilerini incelemiş ve ölçümleri tek meme paternatörü kullanarak gerçekleştirmişlerdir.

Meme tiplerinin püskürtme dağılımları konusunda, birçok araştırma olmasına rağmen, aynı hüzme açısına sahip yelpaze hüzmeli memelerin farklı püskürtme koşullarında (püskürtme yüksekliği ve işletme basıncında) oluşturacağı sıvı dağılımına etkileri bilinmemektedir.

$\mathrm{Bu}$ çalışmanın amacı, tek memeli paternatör üzerinde, yelpaze hüzmeli, hava emişli yelpaze hüzmeli ve hava emişli ikiz hüzmeli memenin farklı püskürtme yüksekliği ve farklı işletme basınçlarında sağladığı hacimsel sıvı dağılımını ve bunlara ait oluşan varyasyon katsayılarını belirlemektir.

\section{Materyal ve Yöntem}

Araştırma Çukurova Üniversitesi Ziraat Fakültesi Tarım Makinaları ve Teknolojileri Mühendisliği Bölümü laboratuvarında gerçekleştirilmiştir. Araştırmada üç farklı meme tipinin bir paternatör üzerinde işletilmesi ile oluşan püskürtme dağılımlarına ait testler yapılmıştır.

Püskürtme testleri için ilaçlama memesi üreten bir firmanın (Teejet Technologies, Co. USA), standart yelpaze hüzmeli (XRN-11003), hava emişli yelpaze hüzmeli (AIXR-11003), hava emişli ikiz hüzmeli (AITJ60-11003) üç farklı meme tipi, iki farklı püskürtme yüksekliğinde (40 ve $50 \mathrm{~cm})$ ve üç farklı püskürtme basıncında (3,4 ve 5 bar) denenmiştir. Yapılan testler, 60 saniye süreyle ve 3 tekerrürlü olarak gerçekleştirilmiştir. Araştırmada kullanılan meme tipleri ve bunlara ait püskürtme desenleri Şekil l'de verilmiştir.

Püskürtme testlerinde kullanılan meme tiplerine ait işletme parametreleri Çizelge 1'de verilmiştir. Araştırmada seçilen meme tiplerinin tamamı, 11003 kod numarasında seçilmiştir. Aynı kodlamadaki memeler, aynı debi ve hüzme açılarında püskürtme yapmaktadırlar. Ancak seçilen memelerin ürettikleri damla çapları ve püskürtme desenleri farklıdır.

Çizelge 1. Püskürtme memelerine ait bazı işletme değerleri (Teejet 2014).

Table 1. Some operating values of spraying nozzle (Teejet 2014).

\begin{tabular}{lccc}
\hline Meme Tipi & Basınç (bar) & Damla Tipi & Debi ( dak $\left.^{-1}\right)$ \\
\hline XRN (11003) & 3 & İnce & 1.18 \\
AIXR (11003) & 3 & Çok kaba & 1.18 \\
AITTJ60 (11003) & 3 & Kaba & 1.18 \\
\hline
\end{tabular}

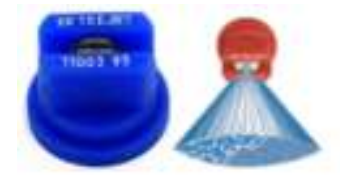

(a)

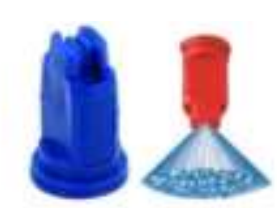

(b)

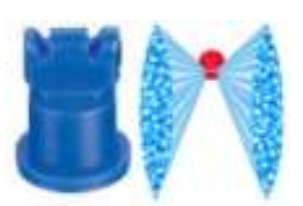

(c)

Şekil 1. Araştırmada kullanılan meme tipleri ve püskürtme desenleri (a-standart yelpaze hüzmeli, b- hava emişli yelpaze hüzmeli, c- hava emişli ikiz hüzmeli meme).

Figure 1. Types of nozzles used in research and spray patterns (a- standard flat fan nozzle, b- air induction flat fan nozzle, c-air induction turbo twinjet nozzle). 
Seçilen meme tipleri ve işletme koşulları için püskürtülen sıvının hacimsel dağılımının belirlenmesinde Şekil 2'de verilen ve $\% 5$ eğim açısına bir paternatör kullanılmıştır. Paternatör 320 $\mathrm{cm}$ genişliğinde ve $150 \mathrm{~cm}$ uzunluğundadır. Paternatörde toplam 56 adet oluk yer almakta ve oluklar arasında $5 \mathrm{~cm}$ mesafe bulunmaktadır. Paternatör, üzerinde püskürtme yapan tek bir meme bulunmakta ve memenin püskürtme yüksekliği mekanik olarak ayarlanabilmektedir. Paternatörün memelere istenen basınçta sıvı akışı sağlayabilmesi için $1.5 \mathrm{~kW}$ motor gücüne sahip 15 bar kapasiteli, ve tank kapasitesi 150 litre olan elektrikli bir kompresör kullanılmıştır. Kompresör tarafından üretilen basınçlı hava basınç tankına aktarılmakta ve sıvı tankından gelen basınçlı sıvı memeye gönderilmektedir. Memeye gelen püskürtme sıvısı, basınçlandırılmış hava da içeren bir tank tarafından sağlanmaktadır. Tank içerisindeki sıvının, basıncını takip edebilmek için bir panoya yerleştirilen kademesiz ayarlı bir regülatör ve buna bağlı bir manometre kullanılmıştır. Basıncın ek olarak daha hassas olarak takip edilebilmesi için memeye yakın noktada püskürtme borusu üzerinde ikinci bir manometre (0-6 bar kapasiteli) takılmıştır. Böylece hedeflenen basınç düzeyleri meme çıkış noktasında da takip edilebilmiştir.

Tank içerisine püskürtme sıvısı olarak, şehir şebekesinden alınan su kullanılmıştır. Kompresörden tanka giren basınçlı hava, tank içerisindeki yer alan sıvıyı aynı basınçta püskürtme memesine doğru hareke etmesini sağlamış böylece memeden istenilen basınçta sıvı akışı sağlanmıştır. Cam tüplerdeki sıvı, dereceli daha küçük beherlere alınarak ölçülmüştür. Böylece püskürtme sonrası numerik olarak kodlanmış cam tüplerdeki sıvı miktarı ( $\mathrm{ml}$ cinsinden) belirlenmiştir.

Paternatör üzerindeki meme askı sistemine üç başlıklı bir meme gövdesi bağlanmıştır. Üçlü meme gövdesinin avantajı, çalışmada kullanılacak tüm memelerin aynı anda sistem üzerinde hazır bulunmasını sağlanmasıdır.

Araştırma kapsamında seçilen işletme parametrelerinde her bir memenin hacimsel dağılım düzgünlüğü Eşitlik 1'de verilen varyasyon katsayısıyla ortaya konmuştur.

$$
\mathrm{CV}=(\mathrm{SS} / \bar{x})^{*} 100
$$

Burada;

CV: Varyasyon katsayısı (\%),

SS: Standart sapma,

$\bar{x}$ : Aritmetik ortalamadır.

$\mathrm{Bu}$ çalışmada aynı debi ve püskürtme açısına sahip bazı meme tiplerinin farklı yükseklik ve basınç düzeylerinde oluşturduğu hacimsel sıvı dağılımları ve varyasyon katsayı değerlerinin belirlenmesi amaçlanmıştır.

\section{Bulgular ve Tartışma}

Araştırma kapsamında elde edilen varyasyon katsayıları istatistiki olarak analize tabi tutulmuştur (Çizelge 2). İstatistiki analizlerde, her bir meme tipi kendi içerisinde farklı püskürtme yüksekliği $(40-50 \mathrm{~cm})$ ve farklı basınç değerleri (3-4 ve 5 bar) için ayrı olarak analiz edilmiştir.

Çizelge 2'de XRN meme tipinde varyasyon katsayıları bakımından istatistiki olarak önemli farklılıklar $(\mathrm{p}<0.01)$ bulunmuştur. Buna göre elde edilen en düşük varyasyon katsayı değeri \%40.7 ile yelpaze hüzmeli (XRN) meme tipinde $40 \mathrm{~cm}$ püskürtme yüksekliği ve 5 bar işletme basıncında elde edilmiştir. Aynı meme tipi için en yüksek değer, \%63.8 ile 50 $\mathrm{cm}$ püskürtme yüksekliğinde ve 3 bar işletme basıncında elde edilmiştir. $\mathrm{Bu}$ araştırmada XRN meme tipinin aynı basıncında, püskürtme yüksekliğinin artması ile varyasyon katsayısı değerlerinin arttığını ve homojen olmayan bir dağılıma neden olduğu görülmüştür. XRN memenin pülverizasyon kalitesinin yükseklik artışından olumsuz etkilediği söylenebilir. Püskürtme basıncı artışına bağlı olarak ise, XRN meme tipinde azalan varyasyon katsayı değerleri sağlanmıştır. Ancak bu meme ile yüksek basınçlarda sürüklenme potansiyelinin arttıracağ söylenebilir. Benzer olarak, Soysal ve Bayat (2006), XRN meme tipinin sürüklenme önleyici özelliğe sahip memelere göre basınç artışından daha fazla etkilendiğini ve sürüklenmenin arttığını belirlemişlerdir.
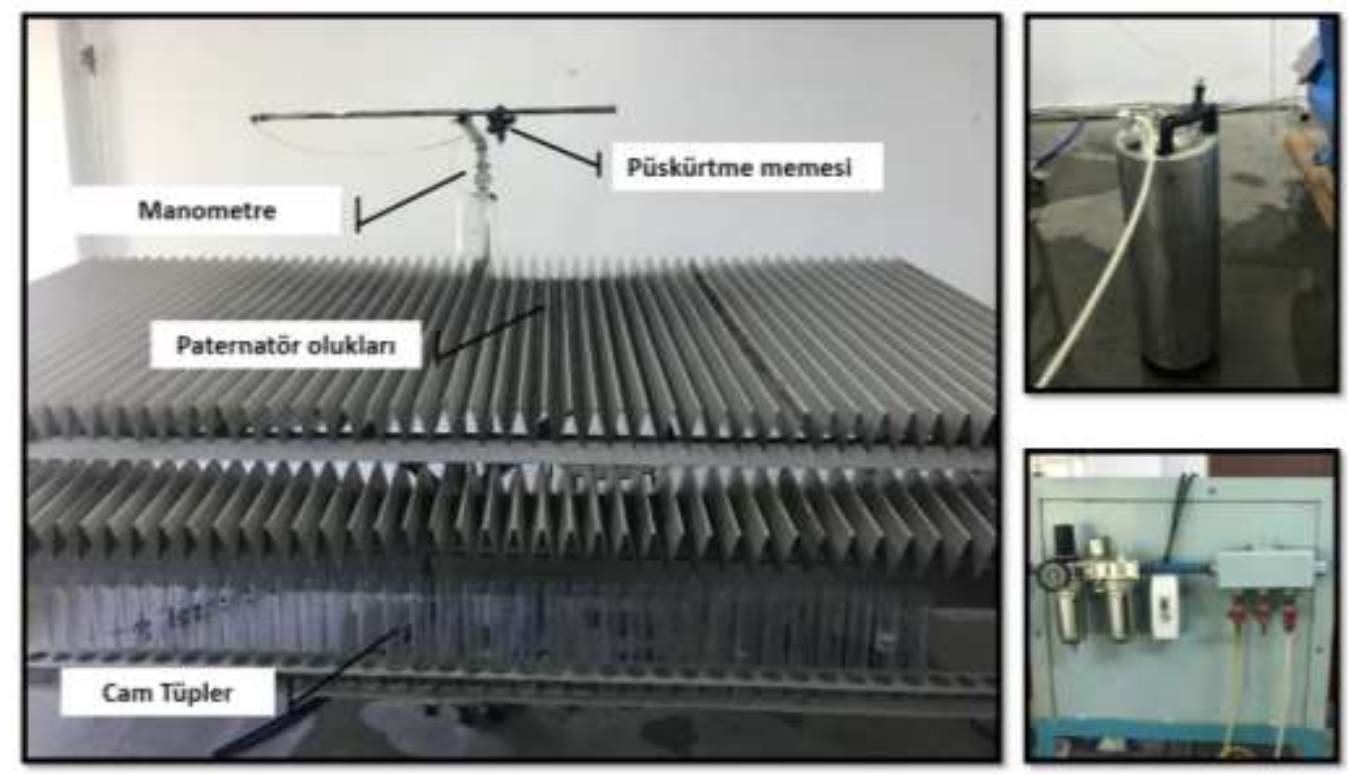

Şekil 2. Paternatör düzeneği, sıvı tankı ve basınç regülatörü.

Figure 2. Pattern system, liquid tank and pressure regulator. 
Çizelge 2. Meme tipi, yükseklik ve basınç değerlerine ait varyasyon katsayıları.

Table 2. Variation coefficients based on nozzle type, spray height and pressure values.

\begin{tabular}{|c|c|c|c|}
\hline Meme Tipi & Püskürtme Yüksekliği (cm) & Püskürtme Basıncı (bar) & $\begin{array}{c}\text { Varyasyon } \\
\text { Katsayıları }(\%)\end{array}$ \\
\hline \multirow{7}{*}{ XRN } & & 3 & $46.5 \mathrm{e}$ \\
\hline & 40 & 4 & $49.8 \mathrm{~d}$ \\
\hline & & 5 & $40.7 \mathrm{f}$ \\
\hline & & 3 & $63.8 \mathrm{a}$ \\
\hline & 50 & 4 & $60.7 \mathrm{~b}$ \\
\hline & & 5 & $54.9 \mathrm{c}$ \\
\hline & & LSD $_{0.01}$ & $1.46 * *$ \\
\hline \multirow{7}{*}{ AIXR } & & 3 & $63.4 \mathrm{a}$ \\
\hline & 40 & 4 & $55.4 \mathrm{c}$ \\
\hline & & 5 & $47.6 \mathrm{~d}$ \\
\hline & & 3 & $65.4 \mathrm{a}$ \\
\hline & 50 & 4 & $59.1 \mathrm{~b}$ \\
\hline & & 5 & $57.0 \mathrm{bc}$ \\
\hline & & LSD $_{0.01}$ & $2.46 * *$ \\
\hline \multirow{7}{*}{ AITTJ60 } & & 3 & $55.0 \mathrm{c}$ \\
\hline & 40 & 4 & $54.5 \mathrm{c}$ \\
\hline & & 5 & $52.6 \mathrm{c}$ \\
\hline & & 3 & $65.9 \mathrm{a}$ \\
\hline & 50 & 4 & $60.2 \mathrm{~b}$ \\
\hline & & 5 & $62.3 \mathrm{~b}$ \\
\hline & & $\mathbf{L S D}_{0.01}$ & $3.70 *$ \\
\hline
\end{tabular}

*: Aynı harfler ile gösterilen değerler LSD testine göre $\mathrm{p}<0.05$ düzeyinde farksızdır. **: Aynı harfler ile gösterilen değerler LSD testine göre $\mathrm{p}<0.01$ düzeyinde farksızdır.

Yine aynı çizelgede AIXR meme tipinde, varyasyon katsayıları bakımından istatistiki olarak önemli $(\mathrm{p}<0.01)$. farklilıklar bulunmuştur AIXR meme tipinde varyasyon katsayısı değerleri $40 \mathrm{~cm}$ püskürtme yüksekliğinde \%47.6-63.4 ve $50 \mathrm{~cm}$ püskürtme yüksekliğinde \%57.0-65.4 arasında değişmiştir. AIXR meme tipinde her iki püskürtme yüksekliği için de basınç değerlerinin artması ile varyasyon katsayısı değerlerinde azalmalar oluştuğu görülmektedir. Bu sonuçlara benzer olarak Sayınc1 ve ark. (2017), tek memeli bir paternatörde konik hüzmeli memede püskürtme basıncı arttıkça varyasyon katsayısı azaldığını belirtmişlerdir. Hassen ve ark. (2013), püskürtme basıncının artmasına bağlı varyasyon katsayısı değerlerinin azaldığını yani yüksek basınç ile yapılan püskürtmenin daha tekdüze bir sıvı dağılımı oluşturduğu belirlemişlerdir.

Hava emişli ikiz hüzmeli (AITTJ60) meme tipinde, varyasyon katsayıları bakımından istatistiki olarak önemli farklılıklar bulunmuştur $(\mathrm{p}<0.05)$. AITT60 meme tipinde varyasyon katsayısı değerleri $40 \mathrm{~cm}$ püskürtme yüksekliğinde $\% 52.6-55.0$ ve $50 \mathrm{~cm}$ püskürtme yüksekliğinde \%60.2-65.9 arasında değişmiştir. Yine bu meme tipinde de diğer memelerde olduğu gibi püskürtme yüksekliği ve basınç değerleri pülverizasyon kalitesini etkileyen faktör olmuştur. Subr ve ark. (2017), pülverizasyon kalitesini etkileyen en önemli faktörün memenin işletme koşulları olduğunu belirtmişlerdir. Yine Sehsah ve Kleisinger (2009), püskürtme dağılımını etkileyen faktörlerin rüzgar hızı, püskürtme yüksekliği ve püskürtme basıncı olduğunu vurgulamışlardır. Bu çalışmada benzer olarak elde edilen verilere göre tüm meme tiplerinde püskürtme yüksekliği ve basıncı memelerden elde edilen varyasyon katsayısı değerlerini etkilemiştir.

Araştırma kapsamında her bir meme tipi için farklı püskürtme yüksekliğinde basınç düzeylerine bağlı olarak belirlenen püskürtme deseni görünümleri Şekil 3, Şekil 4 ve Şekil 5' te verilmiştir.

Şekil 3, 4 ve 5 incelendiğinde, araştırmaya konu olan meme tiplerinin tamamında püskürtme basınç artışına bağlı olarak, oluklarda ölçülen sıv1 miktarlarının arttığı görülmektedir. Yine aynı şekillerde, püskürtme yüksekliği arttığında ise, ıslatma alanının genişlediği görülmektedir. Şekil 3 incelendiğinde, yelpaze hüzmeli (XRN) memeye ait hacimsel sıvı dağılımları, $40 \mathrm{~cm}$ püskürtme yüksekliğinde, $80 \mathrm{~cm}$ 1slatma genişliği elde edilirken, aynı meme için püskürtme yüksekliği $50 \mathrm{~cm}$ olduğunda ıslatma genişliği $110 \mathrm{~cm}$ mesafeye çıkmıştır. Yine aynı şekilde, basınç değerlerinin artması ile meme merkezinde yer alan olukta toplanan siv1 hacminin artmasina neden olmuştur. Hava emişli yelpaze hüzmeli (AIXR) memeye ait hacimsel sıvı dağılımları incelendiğinde ise, $40 \mathrm{~cm}$ püskürtme yüksekliğinde $90 \mathrm{~cm}$ olan 1slatma genişliği, $50 \mathrm{~cm}$ püskürtme yüksekliğinde $110 \mathrm{~cm}$ yükselmiştir (Şekil 4). Şekil 5' te ise, ikiz hüzmeli hava emişli (AITTJ60) meme, $40 \mathrm{~cm}$ püskürtme yüksekliğinde $100 \mathrm{~cm}$ ve $50 \mathrm{~cm}$ püskürtme yüksekliğinde 120 $\mathrm{cm}$ islatma genişliği oluşturduğu görülmektedir. İkiz hüzmeli hava emişli memenin diğer memelere göre daha fazla islatma genişliği sağlamasının nedeni, memenin kenarlara doğru belirli açılarda püskürtme yapabilmesinden kaynaklandığı söylenebilir.

\section{Sonuç}

- Araştırmada kullanılan tüm meme tipleri için, püskürtme yüksekliği ve basıncına değişkenine bağlı elde edilen varyasyon katsayıları istatistiki bakımından önemli bulunmuştur.

- Memelerden elde edilen varyasyon katsayısının düşük olması ilaçlama başarısının daha iyi olacağını ve tekdüze bir dağılımı ifade etmektedir. Araştırmada elde edilen en düşük 


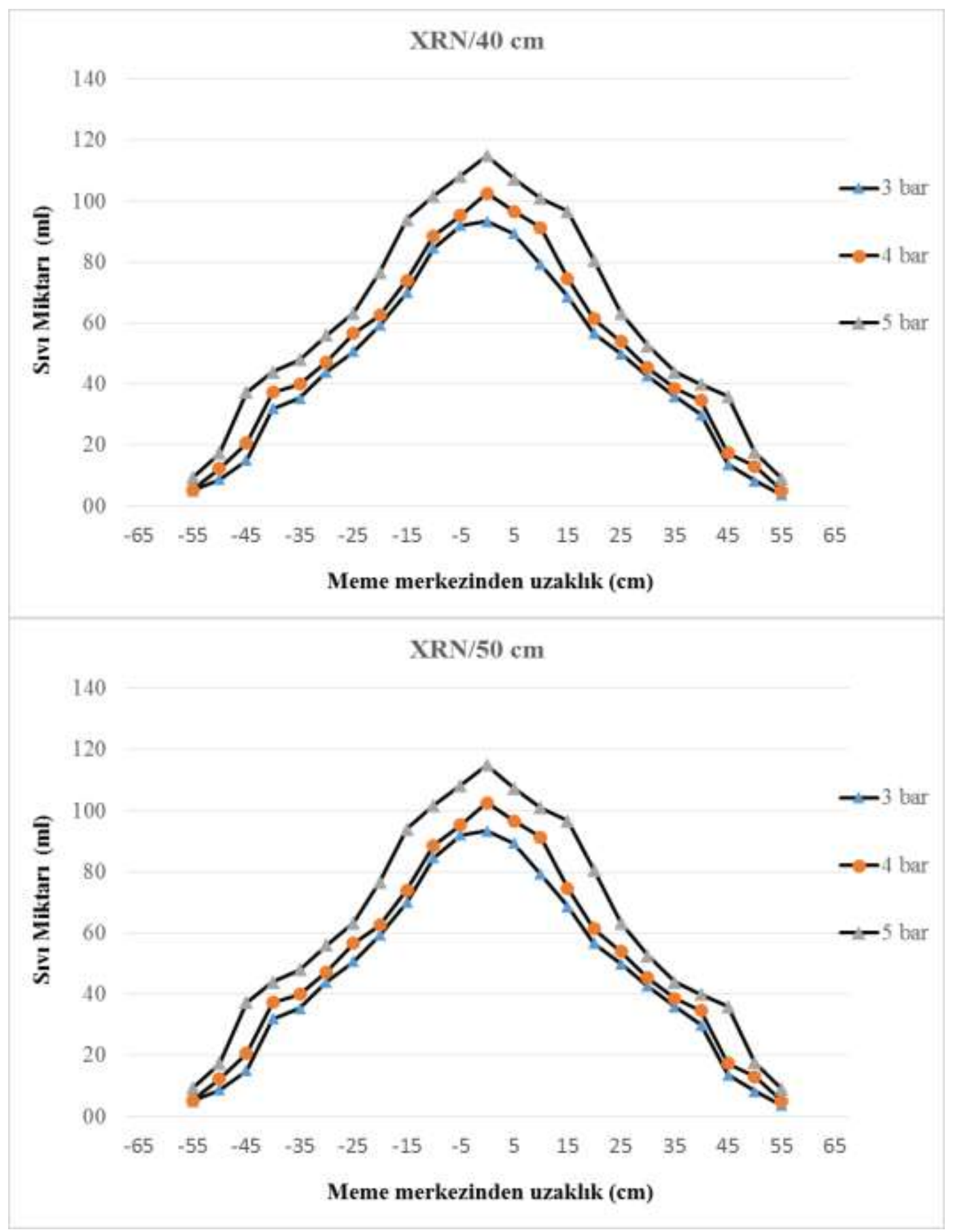

Şekil 3. Standart yelpaze hüzmeli (XRN) memenin püskürtme dağılımı.

Figure 3. Spray distribution of standard flat fan nozzle nozzle (XRN). 


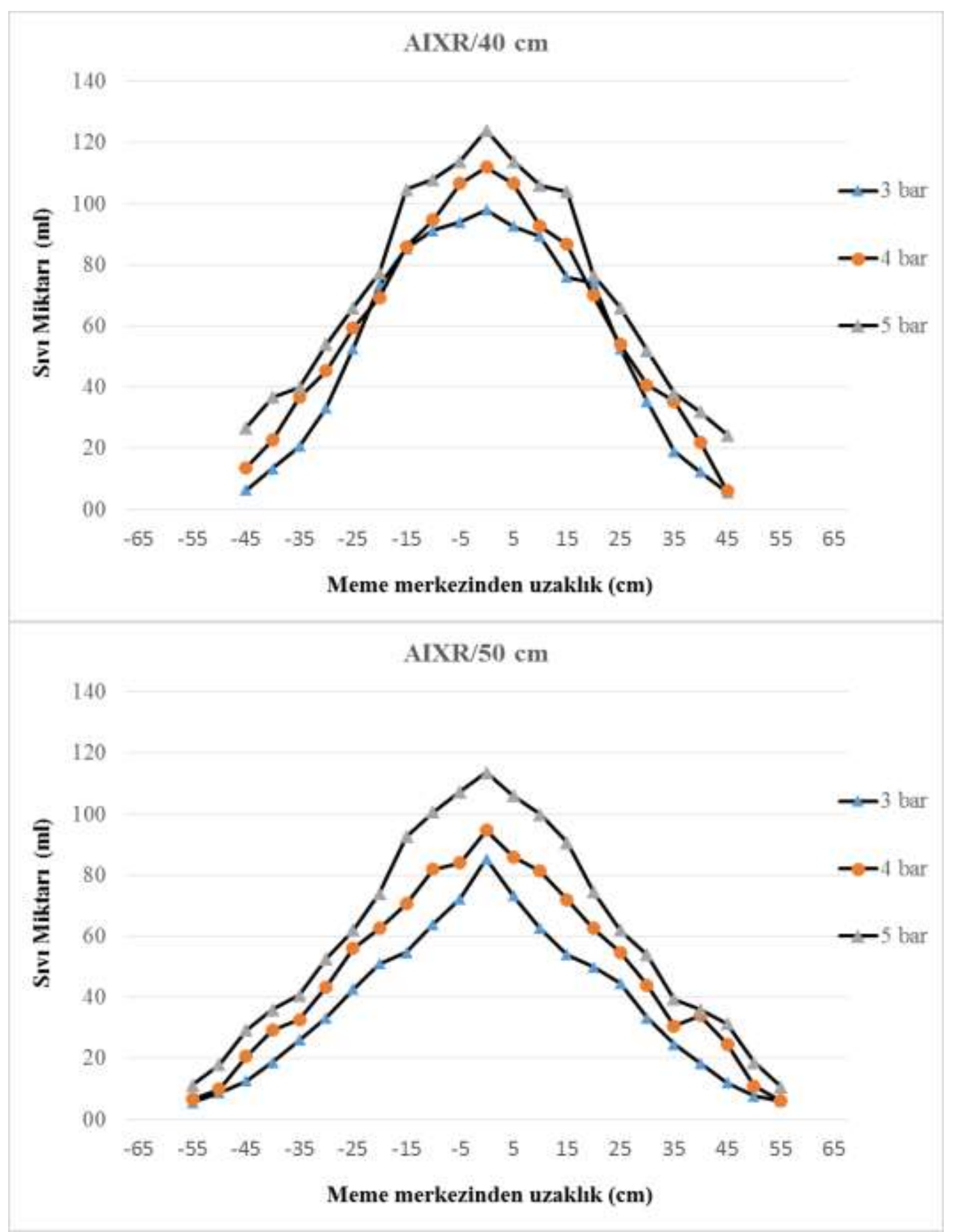

Şekil 4. Hava emişli yelpaze hüzmeli (AIXR) memenin püskürtme dağılımı.

Figure 4. Spray distribution of air induction flat fan nozzle (AIXR). 


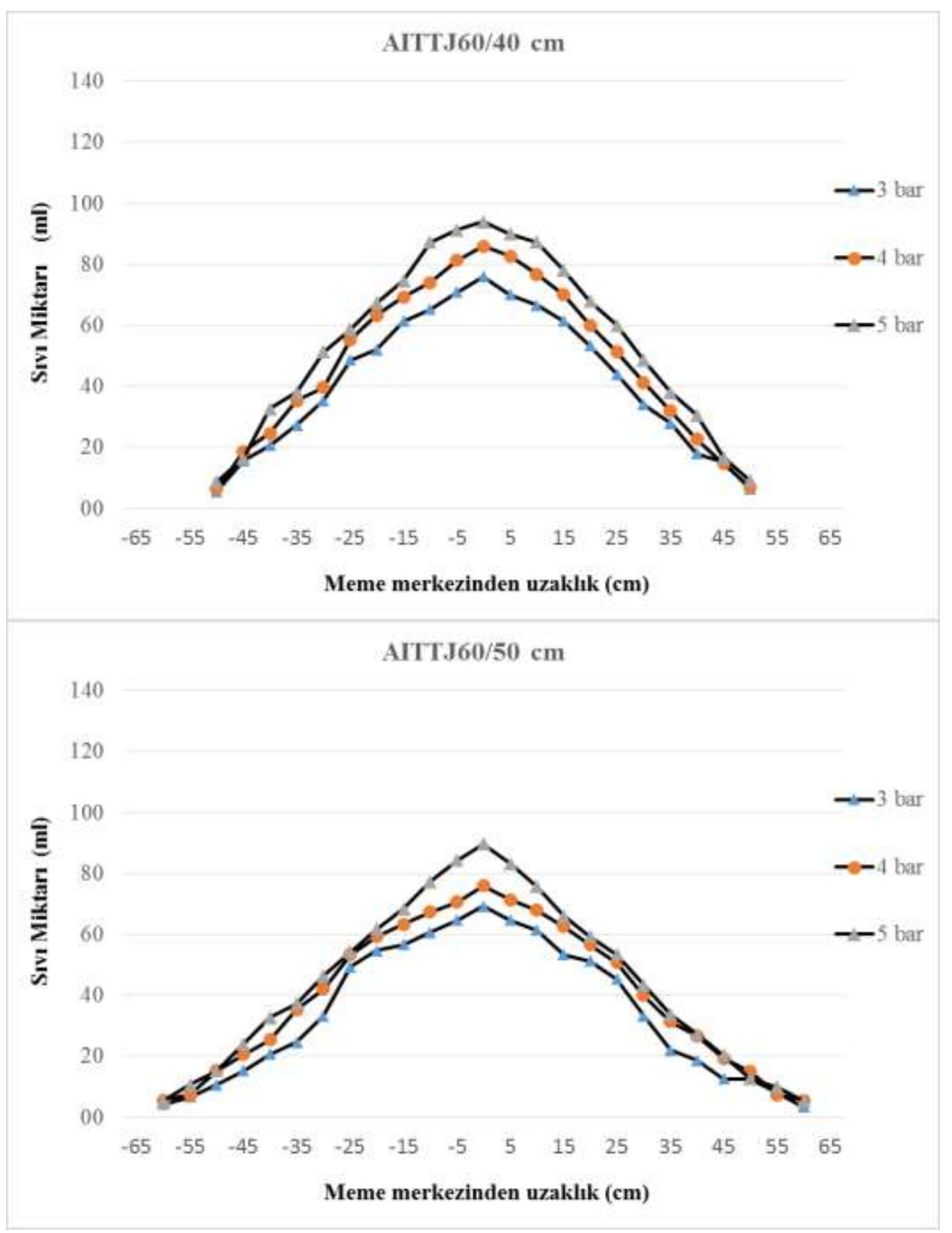

Şekil 5. Hava emişli ikiz hüzmeli (AITTJ60) memenin püskürtme dağılımı. Figure 5. Spray distribution of air induction turbo twinjet nozzle (AITTJ60).

varyasyon katsayıları XRN meme tipinde \%40.7, AIXR meme tipinde \%47.6 ve AITTJ60 meme tipinde \%52.6 değerlerinde bulunmuştur.

- Meme tiplerinin tamamında, püskürtme yüksekliğinde $40 \mathrm{~cm}$ dar açılı üçgen püskürtme geometrisi oluşmasına karşın, yükseklik $50 \mathrm{~cm}$ ' ye çıktığında geniş açılı üçgen püskürtme geometrisi oluşmuştur.

\section{Kaynaklar}

Caner Ö, Tozan M, Güler H (2015) Pestisit uygulama teknolojilerindeki gelişmeler. Türkiye Ziraat Mühendisliği VIII. Teknik Kongresi Bildiriler Kitabi-1, s. 321-349.

Carroll J (2017) The effects of sprayer speed and droplet size on herbicide burn down efficacy. University of Arkansas, Fayetteville USA. http://scholarworks.uark.edu/etd/2435. Erişim 15 Mart 2019. 
Faqiri NL, Krishnan P (2005) Effect of nozzle pressure and wind condition on spray pattern displacement of RF5 and 110-5R nozzles. Applied Engineering in Agriculture 21(5): 747-750.

Forney SH, Luck JD, Kocher MF, Pitla SK (2017) Laboratory and full boom-based in investigation of nozzle setup error effects on flow, pressure, and spray pattern distribution. Applied Engineering in Agriculture 33(5): 641-653.

Hassen NS, Sidik NAC, Sheriff JM (2013) Effect of nozzle type, angle and pressure on spray volumetric distribution of broadcasting and banding application. Journal of Mechanical Engineering Research 5(4): 76-81.

Sayıncı B, Bastaban S (2009) Hidrolik memelerin ilaç uygulama performansını etkileyen faktörler. Türk Bilimsel Derlemeler Dergisi 2(2): 35-41.

Sayıncı B, Çömlek R, Boydaş MG, Kara M, Demir B (2017) Konik hüzmeli memelerde kullanılan girdap plaketlerinin hüzme açısı ve püskürtme paternine etkisi. Gaziosmanpaşa Üniversitesi Ziraat Fakültesi Dergisi 34(Ek Say1): 1-9.

Sehsah EE, Kleisinger S (2009) Study of some parameters affecting spray distribution uniformity pattern. Misr Journal of Agricultural. Engineering 26(1): 69-92.
Soysal A, Bayat A (2006) Herbisit uygulamalarında kullanılan düşük sürüklenme potansiyelli memelerin püskürtme tekniği açısından değerlendirilmesi. Tarım Makinaları Bilimi Dergisi 2(3): 189-195.

Subr A, Milanowski M, Parafiniuk S, Sawa J (2017) Testing the Uniformity of Spray Distribution Under Different Application Parameters. IX International Scientific Symposium Farm Machinery and Processes Management in Sustainable Agriculture. Lublin, Poland. doi: 10.24326/fmpmsa.2017.64.

Teejet (2014) Teejet Technologies Catalog 51 A-M. https://www.teejet.com/CMSImages/TEEJET/documents/catalogs/c at51a_metric.pdf. Erişim 01 Şubat 2019.

Vincelli P, Dixon E (2007) Does spray coverage influence fungicide efficacy against dollar spot? Applied Turfgrass Science 4(1): 52-53.

Višacki V, Sedlar A, Bugarin R. Turan J, Burg P (2017) Effect of pressure on the uniformity of nozzles transverse distribution and mathematical model development. Acta Universitatis Agriculturae et Silviculturae Mendelianae Brunensis 65(2): 563-568.

Womac A, Etheridge R, Seibert A, Hogan D, Ray S (2001) Sprayer speed and venture-nozzle effects on broadcast application uniformity. doi: 10.13031/2013.7011. 